\title{
THE MANY FACES OF TSAI MING-LIANG: CINEPHILIA, THE FRENCH CONNECTION, AND CINEMA IN THE GALLERY
}

\author{
Beth Tsai ${ }^{*}$ \\ Department of Cultural Studies and Comparative Literature, \\ Stony Brook University, Stony Brook, United States \\ email: peijen.tsai@stonybrook.edu
}

Published online: 15 July 2017

To cite this article: Tsai, B. 2017. The many faces of Tsai Ming-liang: Cinephilia, the French connection, and cinema in the gallery. International Journal of Asia Pacific Studies 13 (2): 141-160, https://doi.org/10.21315/ijaps2017.13.2.7

To link to this article: https://doi.org/10.21315/ijaps2017.13.2.7

\begin{abstract}
The Malaysia-born, Taiwan-based filmmaker Tsai Ming-liang's Visage (2009) is a film that was commissioned by the Louvre as part of its collection. His move to the museum space raises a number of questions: What are some of the implications of his shift in practice? What does it mean to have a film, situated in art galleries or museum space, invites us to think about the notion of cinema, spatial configuration, transnational co-production and consumption? To give these questions more specificity, this article will look at the triangular relationship between the filmmaker's prior theatre experience, French cinephilia's influence, and cinema in the gallery, using It's a Dream (2007) and Visage as two case studies. I argue Tsai's film and video installation need to be situated in the intersection between the moving images and the alternative viewing experiences, and between the global and regional film cultures taking place at the theatre-within-a-gallery site. While Tsai's slow film aesthetics can be traced in relation to his prior theatre practice, his installation and film in the gallery are grounded in the belief that cinema needs to be resurrected in the museum. The interrelations between Tsai's video installation and feature films show that they originate from, and are still part of, love for cinema. Tsai's move to the museum space exemplifies the possibility for the future of cinema: it may lose its exclusivity of the collective experience in the movie theatre, yet still privileges the architectural situation of cinema.
\end{abstract}

Keywords: Tsai Ming-liang, French New Wave, cinephile, installation, movie theatres 
Tsai Ming-liang's unique filmmaking has garnered both cinematic and curatorial acclaim. As one of Taiwan cinema's noted art house directors, his work in the last decade has extended from that of feature length to short art films and installation, such as It's a Dream (2007), Erotic Space (2010), The Theater in the Boiler Room (2011), and the Walker series (2012-2014). ${ }^{1}$ Prior to his crossing over to the art gallery, in his films Tsai highlights the cinematic echoing and intertextual citation of French New Wave and New German Cinema, particularly of François Truffaut and Rainer Werner Fassbinder. ${ }^{2}$ The connection between French cinema and Tsai's work can be traced back to What Time Is It There? (2001, hereafter What Time), a film that is said to be haunted by the ghosts of European art films. ${ }^{3}$ In What Time, the protagonist Hsiao-kang (Lee Kang-Sheng, Tsai's signature actor) is seen falling asleep in front of a TV playing Truffaut's Les quatre cents coups (1959); later, the iconic French New Wave figure Jean-Pierre Léaud — best known for playing Antoine Doinel in Truffaut's series of six films - has a cameo scene at the end of the film. At the festival scene, What Time was competing for Palme d'Or at Cannes Film Festival, and went on to win 12 awards for best director, best picture, and best cinematography at festivals worldwide.

Tsai's later films were seen as the ultimate exploration of pure cinematic form, a departure from his early focus on post-colonial Taipei and its social critique. ${ }^{4}$ Such is the hallmark status of Visage, as the Louvre's first collection of the moving image. The all-star cast of Visage includes Jean-Pierre Léaud, Fanny Ardant, Jeanne Moreau, and Laetitia Casta, and this film certainly epitomises the highest form of recognition Tsai received in France. When asked by Henri Loyrette, the Louvre director at the time, "What are you planning to film?" Tsai's initial response was: "I wanted the film to feature Jean-Pierre Léaud and Lee Kang-Sheng, and they will meet on the museum's grounds." ${ }^{5}$ Tsai has never shied away from his obsession with Lee as his muse and his admiration for Truffaut's films. For the director, Visage not only pays tribute to Truffaut, but also restores the time-gap between Truffaut's death and the aged Léaud. Tsai didn't choose Léaud because he expects him to be a box-office magnet; he chose him because he is eager to show the aging side of him, and of French New Wave (figuratively), in his highly reflexive and referential film.

If Visage illustrates a move to bring filmmaking practices and the museum space closer, the importance of approaching Tsai Ming-liang as a transnational auteur is the possibility of a critique of the intricacies between exhibition practices and the question of "Qu'est-ce que le cinéma" in today's ever-changing, multi-media environments. Additionally, for a film to be commissioned by the Louvre represents film festivals' consequential influence 
on fostering international cinephilia because of the role they play in helping a film transition from local production to the global art market. Tsai's making of Visage is not coincidental nor an occasional exploration with alternative viewing conditions in art galleries and the museum space. Instead, Visage should be viewed as a continual exploration of the many themes from Tsai's body of work, particularly his love for the movie theatre. Chiang Ling-ching argues Tsai is to date the only film director in Taiwan who has translated his work into installation that were exclusive for art galleries, while continuing to produce feature films for traditional theatrical release. ${ }^{6}$ Chiang further posits the reason he stands out from other media artists is because he enters the art gallery as a film auteur, which allows him to transplant his signature slow style - long shots and long takes - to a new exhibition space. ${ }^{7}$ Tiago de Luca also points out "it is striking that many filmmakers who have crossed over to art galleries in recent years are often placed under the slow cinema umbrella, and that they often recycle their own cinematic works." ${ }^{8}$ Specifically, Luca is claiming how Tsai's slow style - among other filmmakers in this group such as Béla Tarr, Abbas Kiarostami, Lav Diaz, and Apichatpong Weerasethakulallows a "remarkably smooth transition to the art gallery and the museum as more and more directors associated with the trend make films and installations for these spaces," when "international film festival has been over the past two decades the institutional and culture home of slow cinema."

In this article, I propose Tsai Ming-liang's ventures into new exhibition spaces might be more fruitfully understood as a meta-reflection on the triangular relationship between his theatre experience, the French cinephilia, and cinema in the gallery. I argue Tsai's film and video installation need to be situated in the intersection between the moving images and the alternative viewing experiences, and between the global and regional film cultures taking place at this specific theatre-within-a-gallery site. While Tsai's slow film aesthetics can be traced in relation to his prior theatre practice, his installation and film in the gallery are grounded in his belief that cinema needs to be resurrected in the museum. The interrelations between Tsai's video installation and feature films show that they originate from, and are still part of, love for cinema. Susan Sontag has put it accurately: "If cinephilia is dead, then movies are dead too... If cinema can be resurrected, it will only be through the birth of a new kind of cine-love." ${ }^{10}$ In other words, as film viewing today becomes more and more dispersed and individualised, Tsai's move to the museum space exemplifies the possibility for the future of cinema: it may loses its exclusivity of the collective experience in the movie theatre, yet still privileges a certain architectural set-up of the movie theatre. 
My intention here is to conduct a broader inquiry into the relationship between Tsai's fascination for cinema and his mourning of the movie-going experience as he moved into the realm of film and video installation. In what follows, I start by tracing the key events that have put Tsai forward to his crossing over to art galleries, and situate them in the transnational context. I explore the ways the French cinephiles advocated his film styles, and helped to situate him in the global art market. Through Roland Barthes' critique of the prehypnotic cinematic experience, I proceed to demonstrate how the experimental conditions of It's a Dream and Visage are Tsai's attempt to enter into dialogue with the gallery space, and the possibilities of alternative exhibition. I argue that these exhibitions are not simply about introducing cinema into the gallery. Rather, it is a process of thinking about how an alternative exhibition space can challenge our habitual viewing of cinema.

\section{JOURNEY TO THE MUSEUM}

The 22-minute short The Skywalk Is Gone (2002) marks as a prelude to the filmmaker's subsequent explorations between art cinema and the gallery space. The Skywalk Is Gone is Tsai's first attempt at short art film, which is also his first French commissioned film. As an epilogue to What Time, the film presents two parallel worlds: a young woman wandering around in Taipei, the modern, bustling capital of Taiwan, in search of a skywalk over a busy intersection that she once walked on; at a casting session, a young man is being asked to strip all his clothes off for a role in a pornographic film. The young man's story is a prelude to one of the most controversial (and yet most commercially successful) films Tsai has ever shot in his career to date-The Wayward Cloud (2005). The Skywalk Is Gone stems from a real-life event of a torn-down skywalk - a long-term landmark bridging the iconic Shin Kong Mitsukoshi department store and Taipei's grand central station. If the skywalk in What Time was a place of memory, the short film documented the disappearance of landmarks as the city plans to modernise the existing site. This film, like many of Tsai's subsequent films after The Hole (1998), received help from foreign funding. Commissioned by Le Fresnoy, a public centre for the arts in Northern France that had exhibited many important contemporary art and experimental films, such as Bill Viola, Michael Snow, and others, The Skywalk is Gone advanced Tsai to join other global filmmakers to create gallery or installation versions of their cinematic works.

Tsai's actual first hands-on experience with and crossover to art installation came around 2007, when the Cannes Film Festival wanted to 
commemorate its 60th anniversary. Gilles Jacob, festival president until 2014, commissioned a group of 33 well-known international directors to each make a three-minute film about their experiences with the movie theatre. Each took the interpretations of this assignment very differently, but most reflect a condition of viewing. Many include a film-within-a film, or question the death of cinema, ${ }^{11}$ while others, like Tsai, invoke the filmmaker's own fascination and fetishisation of the theatre, the auditorium chairs, the floating dust in the cone of light from the projector, and so forth. Shot in an abandoned theatre in Kuala Lumpur, It's a Dream draws on Tsai's own childhood memories with grand movie theatres. This short film features a family sharing and eating durian fruit, an East Asian tropical delicacy, and a woman sharing pears on a skewer with the man sitting in the row behind her, all in a silent moment of contact, typical of Tsai's oeuvre.

Shortly after It's a Dream premiered in Cannes, the film travelled to Italy's Venice Biennale, where Tsai participated in a group exhibition organised by the Taipei Fine Arts Museum of Taiwan at the regional pavilion. This work featured the extended 22-minute version (apart from Cannes' three-minute short), and the original seats that were torn from the abandoned theatre were shipped to Venice as part of the installation. The red leather theatres chairs play a major role than being merely a backdrop "seating": audiences were able to (re)create their own unique viewing experience in the pavilion. Tsai cannot hide his fondness for these seats when he describes them as not just any normal seats, but distinguishable in style; they are reusable and, as the spectator sit on the seats to watch the footage he made, "you are in my work," he says to the audience. ${ }^{12}$

It's a Dream also mobilises Tsai's status as both a filmmaker and an artist. As this work was later acquired by the Taipei Fine Arts Museum as the first film to be part of its permanent collection, Tsai said in an interview with Noah Buchan from Taipei Times:

It's the first time that I sold a video installation to a museum and this is the first time for a Taiwanese museum to buy a film as part of its collection. The Louvre was the first in the world to collect film. These events signal that we are now looking at film as a form of art. ${ }^{13}$

He goes on to say that "gradually, my movies find a home, and that is the museum." ${ }^{14}$ For Tsai, there is evidently a move toward gallery space, as an attempt to bridge the gap between artists and filmmakers. In 2011, Tsai turned a boiler room in a former factory in Taipei into an exhibition space for his video work, titled "The Theatre in the Boiler Room: Art Installation." 
In this exhibition, the filmmaker recycled auditorium seats and a large clock (a recurring motif in his films) that were abandoned by the historical Taipei City Hall. There is always an agenda behind Tsai's works, whether they are cinematic or video art; he admits they are all "a conscious act of rebellion against the way cinema is perceived in today's society." ${ }^{15}$ One of his concerns is that historic movie theatres are gradually disappearing and becoming largely forgotten, and he is very much invested in the idea of using cinematic means to preserve time, history, and the artefacts and the experience of movie going. But the question remains: what are some of the implications of his shift in practice?

Tsai Ming-liang's turn to the gallery does not necessarily mean leaving the studio; rather, it should be seen as a creative move toward expanding the format of cinema. In a talk Tsai delivered at National Central University in Taiwan, the filmmaker argued that, although auteur cinema had existed in Taiwan for about 25 years, "The Taiwan New Wave did not really succeed in creating a large cinephilic audience with a distinguished taste and artistic sense." ${ }^{16}$ For Tsai, there is an apparent urge to be fully committed to creating films that challenge mainstream audiences and the spectatorship. While film is essentially a visual art, ${ }^{17}$ audiences do not usually expect to have to go to a museum or gallery to see films - it has been situated in a theatrical setting since the Nickelodeon era. Cinema since its invention has been placed in the darkened theatre, in which audiences are seated according to the fixed spatial arrangement of the screen, chairs and the projector. Commercial or artistic, mainstream or experimental, film screenings are likely to be equipped with a projector, even for visual artists such as painters, sculptors, and photographers who work outside the film industry. For example, when the German-born sculptor Isa Genzken made a short film in 1972 called Two Women in Combat (Zwei Frauen im Gefecht), she insisted that her film had to be shown in a standard movie theatre and not in the museum space. Other pioneers who experimented with moving images in the gallery space include Andy Warhol, Nam June Paik, Jonas Mekas, Valie Export, Martha Rosler, and most recently Stan Douglas and Pierre Huyghe, to name a few. While Tsai may not be making a groundbreaking move to make films for art galleries, what distinguishes him are the cinematic and theatrical dimensions in Tsai's work.

\section{FROM THE LOCAL THEATRE TO THE GLOBAL STAGE}

Tsai Ming-liang's film aesthetics can be traced in relation to his prior theatre practice. In fact, there is a mutual borrowing between the two media. Tsai's 
first stage work was very cinematic: Instant Noodle (1982) was about a boy who loves films so much that he spends all of his money on film festival tickets and dreams about cinema at night. ${ }^{18}$ On stage, he projected classic movies by re-filming the movies with an $8 \mathrm{~mm}$ camera. The filmmaker himself also acknowledges the theatrical presence in his films. In an interview with Shelley Kraicer, Tsai says:

[W] hen I started to make films I found myself pretty much influenced by the stage. It's the long concept of space and time, and the stationary camera. The latter also had something to do with the locations I used. Usually I film in a small room, and as you know there is very limited space for me to move the camera around. On the other hand, if a character is moving outside in a larger space, the camera of course will follow him. So whether the camera moves or does not move has something to do with the characters. In that sense, I feel a kind of freedom. ${ }^{19}$

Tsai's words pinpoint us to his distinct spectatorial positioning in his cinematography, rooted in the legacy of theatre. This dimension of performance can also be credited to the concept of "living theatre," a style that was later adopted by Tsai to use in his televisual and filmic work. Living theatre refers to personal attitude in acting that engages emotions and provokes reactions from the audience. Because this kind of unconventional acting is not grounded in technical competence but personal emotions based on individuals' life experiences, anyone can be an actor playing out his or her own everyday life. At the same time, the actor's bodily movement interacts and reacts to its environment.

Weihong Bao also pointed out how Tsai's films are consistent with his theatre practice, for example, The Hole continues the thematic and formal aesthetics from his one-man stage play, A Wardrobe in the Room (1984). ${ }^{20}$ Produced, directed, and acted by Tsai himself alone, this play is about a guy who talked on the phone with his long-distance partner while an invisible man in the wardrobe quietly listened to the phone conversation. Bao identified Yang Kuei-mei's character in The Hole talking on the phone to an imagined lover parallels Tsai's one-man theatre; meanwhile, the extreme isolation on stage is carried out in Lee Kang-Sheng's solitary existence in the final spotlight scene, created by the hole. ${ }^{21}$ It is worth noting that this kind of acting-nonprofessional, personal, and monotonous - emblematic of Lee's style, was once "too slow and boring" for Tsai when they first started working together on Rebels of the Neon God (1992). ${ }^{22}$ Although Tsai's earlier stage works were often 
unpolished, his minimalist approach set the tone and predicated the potential for making modernist cinema. The way he managed the tension onstage and off-stage affected his future practice in filmmaking. Taking part in the modern theatre movement was an integral part of the experience, but his style had yet been fully explored, until he received an opportunity to direct his first feature length drama All the Corners of the World (1989) for public television.

Tsai's authorial voice also benefits from a long cultivation of the unique French cinephilia tradition. The recent discussions on slow cinema provide an opportunity to raise some important but underexplored questions relating to international cinephilia and Tsai Ming-liang's films. ${ }^{23} \mathrm{I}$ am not suggesting here that, however, slow cinema equates to the French cinephilia. My intention here is to acknowledge this approach in providing more nuanced insights into the intersections of Tsai's filmmaking style, including questions of the slow style, the made-for-festivals films, as well as their imbricated relationship.

Emerging at the moment when technology threatens to obliterate film's materiality, slow cinema is characterised by its minimalism and slow tempo. This cinematic phenomenon is termed "slow" because it often takes too long for action to happen, not because of the absence of action. Here contextualised in a culture of slow cinema, Tsai's films are a temporal site to meditate between stillness and movement. As a resistance to what Gilles Deleuze termed "the movement-image," 24 the viewing process involves "a trope of waiting that may, for some spectators, become a source of boredom."25 This "boredom" lies in the technical use of static long takes (but not slow motion), identified as a hallmark of the cinema of slowness. What distinguishes Tsai Ming-liang among the group of slow cinema filmmakers (excluding predecessors such as Andrei Tarkovsky and Chantal Akerman), according to Song Hwee Lim, is the rich relationship between the French cinephilia and a cinema of the auteur that informs Tsai's work. Tsai's own fascination with the French New Wave is situated among the connoisseurship of art cinema that revolves around issues of class, taste, and intellectual culture. Connoisseurship, in other words, implies the politics of canons: how particular sets of standards and criteria were used for considering and approaching cinema and how tastes were made and constructed by the process of evaluation itself.

In Taiwan, Tsai's film aesthetics - the unbearably long take, static camera, minimal dialogue, and incomprehensible story lines-have bewildered the viewers, and received both raves and criticism. Because of the lack of action and slow tempo, his works were perceived as "box office poison" by local audiences. What changed the local perception was when Tsai's films began getting recognition at international film festivals in the 1990s, particularly 
those of Cannes, Venice, and Berlin. Domestic film critics, festival goers, and cinéastes often find themselves compelled to invoke the names of European auteurs as the lens through which to validate Taiwan New Cinema-François Truffaut, Jean-Luc Godard, Alain Resnais, Michaelangelo Antonioni, to name a few. ${ }^{26}$ European critics were also quick to claim their approval after Taiwan New Cinema made significant inroads into "A-list" festivals in Europe. The famous Cahiers du Cinema critic Olivier Assayas (and now acclaimed filmmaker) even implied that the French New Wave had been resurrected in Taiwan, thereby designating Europe, as the origin of the global new wave phenomenon. ${ }^{27}$

Being associated with both the French New Wave and Taiwan New Wave thus integrated Tsai into the vocabulary of critics and scholars who subsequently measured and marked him with other New Wave directors alike. For example, Olivier Nicklaus was probably one of the first to compare Tsai to Truffaut after viewing Rebels of the Neon God, about which he commented, "Lee Kang-sheng to Tsai Ming-liang is like who Jean-Pierre Léaud is to François Truffaut."28 Guillaume Malaurie in L'Express referred to Tsai's pessimistic approach and rich metaphors of homosexuality rendered in long sequences as "néo-Antonioniesque" (resembling Michelangelo Antonioni). ${ }^{29}$ Some compared the performances. In describing the last scene in Vive L'Amour (1994), Serge Kaganski wrote: "At the end [of the film], when the girl can no longer refrain from sobbing, reminds me of Jeanne Moreau in La Nuit (1961)." ${ }^{30}$ To Noel Herpe, certain moments in Vive L'Amour reminded him not only of Robert Bresson's films, but also novels by Julien Green (American novelist who wrote primarily in French). ${ }^{31}$ French critics also liked to discuss some of the recurring themes and philosophical concerns in Tsai's films, such as la durée (the Deleuzian duration), death, nostalgia, loneliness, emptiness, sleep, mediation, and silence. The most frequent and immediate response to Tsai's c'est long, très long take is that it works as a stand-in for the director's pessimistic look at the vanishing future of cinema: it is dark, ghostly, painful, and desperate. ${ }^{32}$ Without the outreach of festivals and attention to aesthetic qualities and motifs that are articulated and circulated by curators, film reviewers, journalists, and scholars, Tsai's films would not have reached a wider international audience.

Tsai Ming-liang is one of many Taiwanese filmmakers who attained international recognition in recent years. Still, the recognition he received via the international festival circuit surpasses that of his predecessors. It is hard to imagine how Tsai would have attained this iconic status without entering the international festival circuit and receiving subsequent endorsements 
through awards, critical acclaim, and various forms of media exposure. The international visibility of his films ultimately led to the articulation and discussion of themes and visual styles in his films. These stylistic and thematic traits qualified his status as an auteur and set up a collection of anticipating qualities for his next film. In this respect, film festivals provide films with a set of perceived qualities otherwise unavailable outside those networks of exhibition. The favourable French connection and festival conditions thus contributed to the evolving and historically unique conceptions of Tsai Mingliang's films.

\section{TSAI MING-LIANG'S MOVIE THEATRE}

So how did Tsai Ming-liang end up at the Louvre? It is said that before the Louvre decided on Tsai, the museum curator went down a list of more than 200 directors before the Louvre made its selection. Tsai also believed that the Louvre wanted to work with him as early as 2004, after Goodbye, Dragon Inn (2003) was screened at Venice. ${ }^{33}$ Here I suggest the interrelations among the recent set of Tsai's films and video installation present an intriguing point of entry into the peculiar dimension of Tsai's artistic practice: that of the cinematic apparatus. In their chronological trajectory, the recurring theme that binds Tsai's films together is his love for the movie theatre. In What Time, HsiaoKang, who sells watches on the streets of Taipei, wanders into an old movie theatre, steals a clock from the corridor, and sneaks into the auditorium, where he attempts to reset the clock - as he has been doing, bizarrely, throughout the film. Hsiao-Kang's scheme is sabotaged by a dumpy man who follows him into the theatre and snatches the clock from him and lures him into the men's bathroom, only to find the strange man standing naked in an open stall, with the stolen oversized clock covering his crotch area. It is humorous, whimsical, camp, and queer, all at the same time. In another scene, Hsiao-Kang is seen drinking a bottle of red wine (a way of bringing himself closer to the French culture) on a rooftop and climbs onto the clock tower, attempting to adjust the clock hands with an extended grip. Hsiao-Kang is seen performing a very Harold Lloyd-esque stunt; by that I mean a post-colonial reference to the famous clock tower scene in Safety Last! (1923) when Lloyd grabs the hands of a clock and can barely hang on to the tower. Here, the reference is not merely an intertextual reference to a film from the older silent period but also, through re-imagining and the queering of time, reflects a kind of dialogue between East and West about the modernity gap. 
The intersection of time and space is further explored in Tsai's next feature film, Goodbye, Dragon Inn (hereafter Goodbye), where the film consists shots and long takes of corridors, dark rooms, and bathroom stalls in the later demolished Fu-ho Grand Theater - the same movie theatre seen in What Time. The opening scenes of Goodbye, like the title, literally pay homage to a classic Chinese wuxia film: King Hu's Dragon Inn (1967). This is done by intercutting and juxtaposing the illuminated screen in front, along with the darkened theatre, red auditorium chairs, and a crowd of spectators' heads, producing reflexivity of the conditions of cinematic viewing. One who is certainly an aficionado of Tsai's works would immediately spot a cameo appearance of Tsai's head among the audiences watching Dragon Inn. Alternating between the screen and the spectator, the projection of King Hu's film runs through the full length of Goodbye, with off-screen characters drifting around the theatre like ghosts. By the converging and colliding use of martial arts films from the glory days of Taiwanese cinema, Goodbye is really saying goodbye to the golden age of Chinese cinema.

If the example of Goodbye highlights both the conditions of film projection and the film itself as a text, then the reuse of theatre chairs in $I t$ 's a Dream demonstrates the traces and extension of "haunted cinema." The peculiarity of this installation is not just about the memory of cinema but the space the seats inhabit. The way the seats are set up has little resemblance to typical theatre seating. Instead, the red cloth chairs are placed diagonally, with no rows of chairs lined up parallel to the screen or to others; the seats are intentionally set up to intersect with each other, disrupting the customary sense of viewing. As the director declaimed, the audience is participating in his work. When his film is placed in the white gallery space rather than the black movie theatre, the viewing experience has been transformed from the darkness of the movie theatre Roland Barthes proposed in "Leaving a Movie Theatre" to art appreciation in a white cube. ${ }^{34}$ Notably, when watching a movie in a theatre, one is less compelled to move about or leave in the middle of the screening, contrary to the flexibility the spectator would have in an art gallery because it is situated in a (seemingly) open space. In addition, the constant looping of the film screening removes the exclusive regulated relationship a theatre film screening would have with time and space. Art patrons enjoy this non-exclusiveness of the screening in that one could enter, leave, and re-enter the viewing at one's convenience. In this respect, while Goodbye proclaims the death (or memory) of cinema, this installation of the theatre seats announced the resurrection of cinema. As Andrew V. Uroskie notes, in thinking about the postwar emergence of cinema in the gallery space as expanded cinema, "It is 
not a question of simply introducing cinema into the gallery situation. Rather, it was a process of thinking how the temporality and kineticism of the moving image might be divorced from its habitual situation within [the] commercial theatrical project." ${ }^{15}$ This is not to say that all work placed in the gallery space is not theatrical, or that any work placed in a movie theatre should not be considered art. The point here is the emergence of a new institutional situation for moving images, one divorced from the theatrical viewing of cinema, an opportunity to re-approach cinema in this conflict situation.

While the spectatorial experience of It's a Dream takes place in a mock theatre space, the deliberate disorientation of cinema viewing implies a more precise construction of the spectator as a conscious dreamer. The installation is composed of two elements that cannot be separated: the film on the screen and the chairs taken from a "dead" movie theatre. Just like the cinematic apparatus is a totality of what constitutes the viewing situations by ways of (1) the film itself; (2) the way moving images are constructed (cinematic language and techniques); (3) the conditions of film projection; and (4) the conscious as well as unconscious perceptual process of spectatorship. ${ }^{36}$ Tsai Ming-liang is deploying the concept of interpellation when he asserts that you, as the spectator, are in his work because, by sitting on chairs that are both in the work and outside of it, on screen as an imprint and off screen as actuality, the spectator is in a space watching a space that no longer exists, mutually reinforcing the spectator as always already the subject. When one sits on the chair watching the same chairs on screen, it not only provides a ruptured timespace, but also, because of the particular way chairs are placed, people can spend time observing their neighbours and let other art patrons block or disturb one's view. Without the blackness of the movie theatre and the self-regulating courtesy to others to make the spectator's entering a dream state a smoother transition, Tsai purposefully situates the spectator to be fully aware of oneself, of the viewing experience, and of the existence of the neighbours interfering with oneself. While the original spatio-temporality of the Malaysian movie theatre has entered into the cinematic space, the spectators actively making use of the real space is also a reconstruction and resurrection of the cinema. "It sounds like a contradiction," Tsai says, "but movies need to leave today's theatres in order to be resurrected." 37

When the spectator sits on the chair that is "borrowed" from the past, stripped from a foreign theatre, and stretched out from the onscreen space, this totality of viewing experience conjures rich possibilities for viewers to explore their own memories of cinema. Similarly, Visage is also about leaving the movie theatre and engages in a meta-cinematic cruising of memory and 
nostalgia. Visage is Tsai Ming-liang's ninth feature film, and is also not his first transnational production between Taiwan and France. His fourth feature, The Hole, was commissioned by French production company Haut et Court and the European channel La Sept-Arte as part of their fin de millénaire series $2000 \mathrm{Vu}$ Par (as a result, the film has two cuts: a 95-minute feature film and a 60-minute television version). Tsai's eighth film, I Don't Want to Sleep Alone (2006), was financed as part of the New Crowned Hope project, a project established by American theatre director Peter Sellars to celebrate the 250th anniversary of Mozart's birth, and was loosely based the story on Die Zauberföte (The Magic Flute). If these cross-cultural productions predicated Tsai's working with the Louvre, it is also worth noting that instead of presenting the glamorous side of the museum, Tsai has his eyes set on the secret chambers, dusty shafts, and grimy underground tunnels. The film centres on a Taiwanese director, HsiaoKang, attempting to shoot a film on the Louvre grounds. The film-within-afilm is based on the story of Salome, the stepdaughter of Herod who asked for the beheading of John the Baptist. Like many of Tsai's previous films, Visage deals with alienated people wandering around in an empty museum. The film also paints a vague, puzzling, but aesthetically pleasing picture that bears the least sense of narrative of all of Tsai's films..$^{38}$

While Tsai attempts to paint a pretty picture of many faces with cinema, the Louvre is the most important facade the director tries to visualise. Like the characters who wander in this labyrinth, struggling to find an exit, the film invites its onlooker to shuttle between narrow corridors, prowling in freight elevators, checking out a web of underground tunnels. While the film title literally translates to face, we are not really looking at the appearance of things, but exploring the façade of museum buildings that operate like organisms. Interestingly enough, among the vast collections and galleries, Tsai only opted to show the most famous Grand Gallery at the end, where Léaud climbed out of a hole in the Louvre wall below a Leonardo da Vinci painting of St. John the Baptist. Visage makes sense between what is shown and the gaps between the scenes, trying to break through isolation and parallel worlds. In other words, the film's rich symbolism is rendered in the physical space and the actors reacting to the surroundings of unseen fears and urges. Visage in ways echoes Goodbye, which is filled with metaphors of ghosts and the living people. There is one scene with Jeanne Moreau and Fanny Ardant, who appear out of nowhere occupying the famous, luxurious oval dinner table in the room of Napoleon III's apartment, while later the same composition is repeated, chairs empty, as if they simply vanished like ghosts. Visage is also a very referential film, containing nods to other filmmakers as if trying to recover 
its past lives. At one point in the story Lee Kang-Sheng is outside with Léaud and a little bird, and Léaud says about the bird: "Titi is a great director." The conversation is followed by exchanges of directors' names: Pasolini, Fellini, Antonioni, Orson Welles, Buster Keaton, Murnau, Truffaut, Carl Theodor Dreyer, Tarkovsky, and Kenji Mizoguchi. In Visage's final segment, ghosts and fantasies manifest for a moment as characters perceive each other: Salome comes to kill Lee in a silent, seductive dance; Ardant comforts Léaud as they look into the mirror and tells him he will be okay; the model shuts off the apartment light as she says to her boyfriend, "Just look at me and you'll love me." As characters begin to reconcile, these three relationships symbolise people reaching for what they can't see or even do.

Whether the characters are real or illusions hardly matters. Unlike Buster Keaton in Sherlock Jr. (1924) who climbs into the movie screen and lingers between different frames and landscapes, Visage is literally displaced in terms of the actual screening venues. When the film premiered in Taiwan, the screening took place, for the first time, at the National Theater Concert Hall in Taipei. Built in 1987, this hall is the most prestigious venue in the capital of Taiwan to host world-class musical, dance, and theatre performances, but never in its history had it shown cinema. To show a film in such an unusual space encourages a different kind of movie-going experience. Let us return to Barthes' mediation on "Leaving the Movie Theatre." Barthes argues that the captivating story on screen is produced by the mechanism and architecture of cinema. A successful cinematic event is one in which the spectator is perpetually fixed to the mirror-screen, temporarily gluing the cinephile's gaze to the screen. Barthes describes this situation as pre-hypnotic and prefigured by the darkness of the theatre: "Not only is the dark the very substance of reverie; it is also the 'colour' of a diffused eroticism... it is in this urban dark that the body's freedom is generated." ${ }^{139}$ Most importantly, it is just not the naturalness of darkness, but where our bodies are at: "Whenever I hear the word cinema, I can't help thinking hall, rather than film." ${ }^{40}$ Barthes asks us to accept the hypnotic effects of cinema largely because of the darkness of the theatre and the architecture of the cinema experience (sound, the space of projection, the mass), making possible bliss of discretion (anonymous, populated, numerous). The fascination of the cinema requires us to divorce our minds from our bodies, in which the spectator is both conscious of and unconscious of the dream state one enters, facilitated by the darkness of the movie theatre. So what happens when modernist filmmakers attempt to move beyond the dichotomy of either transfixed by the mirror images or disruption to the mechanisms of projection? 
"This is not the most appropriate site to show movies," said Tsai on stage, as he gleefully introduced Visage to premiere at the National Theater Concert Hall on 22 September 2009. Tsai continued to remark apologetically to the audience that they might notice a few scratchy noises caused by the running film reel (because the projector was not set up in a separate room), or worsewhen sound failed to synchronise during projection. Tsai's concerns may be too trivial for anyone growing up watching films with a running projector (instead of the digital projection) or who has hands-on experience with filmmaking, but it is precisely the working of cinematic apparatus that makes most audiences forget their surroundings when watching a movie. Audiences are "stitched"41 into the diegetic world by a chain of cinematic techniques; in other words, spectators perceive the narrative from images and their symbolic meanings, and these registers do not require exploration of events happening outside the frame. So when a director like Tsai urged his audiences not to pay attention to what was happening in the actual space where his film was to premiere, he inadvertently highlighted his audiences' senses to look out for any extra-diegetic incidents or technical mistakes, turning this ordinary viewing experience into an unordinary one. If going to the cinema evokes a site specific, pilgrimatic experience to cinephiles that is akin to going to the art gallery or museum to view the original paintings, Visage's non-traditional exhibition venue highlights the space as the protagonist, and in such concept the space configuration is the main drive to the viewers' sensory experience of image operations. In short, this exhibition practice decentres the aura of the movie theatres.

\section{CONCLUSION}

Situating moving images in art galleries, museums, or music hall shows how Tsai Ming-liang crosses the boundaries between cinema and theatre. These exhibitions represent not just Tsai's move to recycle abandoned objects and places; he is also criticising the modern lifestyle of fast speeds, overconsumption and waste in which objects, along with the memories of using them, were simply disregarded. In What Time, the movie theatre is only part of the larger intersecting dislocation of time and space (Paris and Taipei, the traveller and the local merchant), and this temporal relationship of simultaneity is extended with Goodbye as it returns to an abolished movie theatre. It's a Dream displaces patrons and spectators alike in between the darkened theatre and the white gallery. While the original spatio-temporality of the cinematic apparatus is 
preserved in Tsai's feature length films, It's a Dream and Visage represent a spatial practice that marks the transition from movie theatres to new exhibition sites - a move to prompt audiences to rethink the meaning of cinema. In the long run, what Tsai Ming-liang is doing is not just about embracing new ways of resurrecting the cinema, but about an alternative home to cinema (as opposed to the digital platform). Given the transnational nature of content and production, Tsai's films offer a critique of the intricacies between exhibition practices and how audiences consume plural understanding of cultural flow and the moving image.

\section{NOTES}

* Beth Tsai is a doctoral candidate in the Department of Cultural Studies and Comparative Literature at Stony Brook University. Her publications have appeared in Journal of Asian Cinema, Quarterly Review of Film and Video, and Film Appreciation. She is currently working on her dissertation titled "Transnational Images in a Global Frame: Film Festivals and Taiwan Cinema through the Lens of Hou Hsiao-hsien and Tsai Mingliang."

1 I am referring to Walker (2012), Walking on Water (2013), and Journey to the West (2014). These films feature Lee Kang-Sheng as a monk in a red robe walking unbelievably slowly through the streets of Hong Kong, Tsai's hometown of Kuching, Malaysia, and Marseille, France. I am also aware of Tsai's latest feature film Stray Dogs (2013) is quite reflective of this respect - a director gradually making his way into the museum by concentrating on making films for fine art museum, and features Taiwanese artist Kao Jun-Honn's work in the film. However, this is beyond the scope of this article.

2 Tsai stated time and again his fascination with François Truffaut's films in many interviews. For one, see Bordeleau, E., Chang, C-C., Lin, S. and Tsai, B., "On the Uses and Misuses of Cinema," Senses of Cinema, No. 58 (March 2011), n.p.

3 Fran Martin, "The European undead: Tsai Ming-liang's temporal dysphoria," Senses of Cinema, No. 27 (July 2003), n.p.

$4 \quad$ I am suggesting a shift of focus but not necessarily mean that there is a void of social critique in his later works, such as Stray Dogs. This observation is made in relation to Tsai's trajectory of filmmaking. For instance, in his first film, Rebels of the Neon God (1992) and the documentary he made four years later — both reflect an immediate concern about AIDS in Taiwan. Gradually, Tsai's films move toward an elaborate treatment of disintegrated times, spaces, and human relationships, as Wen Tian-Xiang suggested, the films "digging deeply into modern subjectivity almost without any sense of historicity." See Wen, T-X., Guangying dingge: Tsai Ming-liang de xinling changyu [Freeze-frame in light and shadow: The spiritual site of Tsai Ming-liang] (Taipei: Hengxing, 2002), 9.

5 Tsai Ming-liang, interview by Peter van der Lugt, International Film Festival at Rotterdam, 2010. 
6 Chiang, L-c., "Architecture as the key to connect film installations and film aesthetics: Using Tsai Ming-liang's works as example," Journal of Taipei Fine Arts Museum, No. 23 (2012), 55.

7 Ibid.

8 de Luca, T., "Slow time, visible cinema: Duration, experience, and spectatorship," Cinema Journal, Vol. 56, No. 1 (Fall 2016), 23-42.

9 Ibid., 24-35.

10 Sontag, S., "The decay of cinema," The New York Times (25 February 1996).

11 de Villiers, N., "We are the World Cinema: Chacun son cinéma, ou, Ce petit coup au coeur quand la lumière s'éteint et que le film commence," Senses of Cinema, No. 45 (November 2007), n.p.

12 Bordeleau et al. (2011).

13 Tsai Ming-liang, interview by Noah Buchan, Taipei Times (Taipei, Taiwan), 25 March 2010.

14 Ibid.

15 Vagenas, M. G., "Filmmaker Tsai Ming-liang says his work should be appreciated slowly," South China Morning Post (Hong Kong), 27 August 2013.

16 Bordeleau et al. (2011).

17 Ricciotto Canudo, the Italian-born film critic who started the Club des Amis du Septième Art in 1921, was the first to label cinema as "the Seventh Art."

18 Kraicer, S., "Interview with Tsai Ming-liang," Positions: East Asia Cultures Critique, Vol. 8 No. 2 (Fall, 2000), 579-588.

19 Ibid, 583-584.

20 Bao, W., "Biomechanics of love: Reinventing the avant-garde in Tsai Ming-liang's wayward 'pornographic musical,"' Journal of Chinese Cinemas, Vol. 1, No. 2 (2007), 143.

21 Ibid

22 Bordeleau et al. (2011).

23 See Song, H. L., Tsai Ming-Liang and a cinema of slowness (Honolulu: University of Hawaii Press, 2014); de Luca, T. and Jorge, N. B. introduction to Slow Cinema, ed. de Luca, T. and Jorge, N. B. (Edinburgh: Edinburgh University Press, 2016); Luca (2016).

24 Taken from Henri Bergson's concept of duration (durée), Deleuze regards film as a particular kind of "thought" or "time" machine that allows thinking (or cinematographic thinking), though not unconsciously, to be made visible and meditated through cinematic images. Basically, Deleuze's conception of cinema is a medium for imagining and imaging the world. See Gilles Deleuze, Cinema 2: The Time-Image (Minneapolis: University of Minnesota Press, 1989).

25 Song, Tsai Ming-Liang, 16.

26 Here I refer to a group of domestic film critics who carried literary influences and Western theories into defending Taiwan New Cinema, including Peggy Chiao Hsiungping (film scholar and critic), Edmond Wong (director of Taipei Film Archive), Hsiao Yeh (novelist, writer, producer at CMPC), and Li Yu Hsin (film critic, journalist).

27 Assayas, O., "Notre Reporter en République de Chine," Cahiers du Cinéma, No. 366 (1984), 57-66. 
28 Nicklaus, O., "On retrouve les obsessions du cineaste : famille sclérosante, appartement vide et inondé. De film en film, on reconnaît les mêmes acteurs, en particulier [Kangsheng Lee], qui est à Tsai Ming-liang ce que Jean-Pierre Léaud était à François Truffaut. Une reference," La Croix (France), 25 March 1998. My translation.

29 Malaurie, G., "Tsai Ming-liang autopsie, au fil d'ellipses et de hors-champs signifiants, une jeunesse insoumise et pessimiste. Et égrène solitude, incommunicabilité, (homo) sexualité en de longs plans-séquences riches en métaphores (...) Parcouru de cercles d'attirances, de répulsions et de sentiments dévastés, le style néo-antonioniesque de Tsai Ming-liang s'imposait déjà en 1992 et en imposait. Il s'est depuis, amplement confirmé," L'Express (France), 26 March 1998. My translation.

30 Kaganski, S., "A la fin, quand la jeune fille ne peut plus sèpêcher de sangloter, telle Jeanne Moreau au bout de La Nuit..." Les Inrockuptibles (France), 5 April 1995. My translation.

31 Herpe, N., "Vive l'amour, l'enfer du même," Positif No. 410 (April 1995), 25.

32 Morice, J., "[...] c'est d'un pessimisme glaçant quant à l'avenir du cinéma... obscure et fantomatique," Télérama (France), July 21, 2004. My translation.

33 Tsai, Taipei Times, 13.

34 Barthes, R., "Leaving the movie theater," in The Rustle of Language, trans. Howard, R. (Oxford: Blackwell, 1986), 345-349.

35 Uroskie, A. V., "The philosophical toy as model: Duchamp, Breer, and the postwar emergence of cinema in the gallery space," Secuencias 32 (2011), 35.

36 Stam, R., Burgoyne, R. and Flitterman-Lewis, S., New vocabularies in film semiotics (New York: Routledge, 1992), 145.

37 Tsai, Taipei Times, 13.

38 Michelle Bloom has already provided a detailed intertextual reading of Visage and Sinofrench culture, invoking readings of Truffaut's films, Oscar Wilde's Salomé, 1940s Shanghai music, and the painting of Leonardo da Vinci's St. John the Baptist. For the sake of the limited space in this article I will not repeat the arguments here. My attention, however, is given to the façade of the space within the film and of the exhibition practice. See Bloom, M., "The intertextuality of Tsai Ming-liang's Sinofrench film, Face," Journal of Chinese Cinemas, Vol. 5 No. 2 (2011), 103-121.

39 Barthes, "Leaving the Movie Theater," 346.

40 Ibid.

41 Silverman, K., "Suture," The subject of semiotics (New York: Oxford University Press, 1984), 194-236.

\section{BIBLIOGRAPHY}

Assayas, O. 1984. Notre reporter en République de Chine. Cahiers du Cinéma 366: 57-66. Bao, W. 2007. Biomechanics of love: reinventing the avant-garde in Tsai Ming-liang's wayward 'pornographic musical.' Journal of Chinese Cinemas 1 (2): 139-160, https://doi.org/10.1386/jcc.1.2.139_1.

Barthes, R. 1986. Leaving the movie theatre. In The Rustle of language, trans. Howard, R., 345-349. Oxford: Blackwell. 
Bloom, M. 2011. The intertextuality of Tsai Ming-liang's Sinofrench film, Face. Journal of Chinese Cinemas 5 (2): 103-121, https://doi.org/10.1386/jcc.5.2.103_1.

Bordeleau, E., Chang, C-C., Lin, S. and Tsai, B. "On the uses and misuses of cinema," Senses of Cinema 58: n.p.

de Luca, T. 2016. Slow time, visible cinema: Duration, experience, and spectatorship. Cinema Journal 56 (1): 23-42, https://doi.org/10.1353/cj.2016.0052.

de Luca, T. and Jorge, N. B. 2016. Introduction. In Slow Cinema, ed. de Luca, T. and Jorge, N. B., 1-21. Edinburgh: Edinburgh University Press, https://doi.org/10.12987/ yale/9780300218534.003.0001.

de Villiers, N. 2007. We are the world cinema: Chacun son cinéma, ou, Ce petit coup au coeur quand la lumière s'éteint et que le film commence. Senses of Cinema 45: n.p.

Deleuze, G. 1989. Cinema 2: The time-image. Minneapolis: University of Minnesota Press. Herpe, N. 1995. Vive l'amour, l'enfer du même. Positif 410: 25-26.

Genzken, I. 1974. Zwei Frauen im Gefecht [Two women in combat]. Dusseldorf: Kunstakademie.

Kaganski, S. 1995. Les Inrockuptibles (France), 5 April.

Keaton, B. 1924. Sherlock Jr. Hollywood: Buster Keaton Productions.

Kraicer, S. Interview with Tsai Ming-liang. Positions: East Asia Cultures Critique 8 (2): 579-88.

Lim, S. H. 2014. Tsai Ming-liang and a Cinema of Slowness. Honolulu: University of Hawaii Press, https://doi.org/10.21313/hawaii/9780824836849.001.0001.

Malaurie, G. 1998. Cinéma: La rivière. L'Express (France), 26 March.

Martin, F. 2003. The European undead: Tsai Ming-liang's temporal dysphoria. Senses of Cinema 27: n.p.

Morice, J. 2004. Good bye Dragon Inn. Télérama (France), 21 July.

Neymeyer, F. and Taylor, S. 1923. Safety Last! Buffalo: Pathe Exchange.

Nicklaus, O. 1998. Les films à l'affiche. La Croix (France), 25 March.

Silverman, K. 1984. "Suture," The subject of semiotics. New York: Oxford University Press.

Sontag, S. 1996. The decay of cinema. The New York Times, 25 February.

Stam, R., Burgoyne, R. and Flitterman-Lewis, S. 1992. New vocabularies in film semiotics. New York: Routledge.

Tsai, M-1. 1981. Instant noodle. Taipei: National Performing Arts Center.

. 1984. A wardrobe in the room. Taipei: National Performing Arts Center.

1989. All the corners of the world. Taipei: Chinese Television System.

1992. Rebels of the Neon God. Taipei: Central Motion Pictures.

1994. Vive l'amour. Taipei: Central Motion Pictures.

. 1998. The hole. Paris: Haut et Court.

.2001. What time is it there? Taipei: Homegreen Films.

2002. The skywalk is gone. Tourcoing, France: Le Fresnoy Studio National des

Arts Contemporains.

2003. Goodbye, dragon inn. Taipei: Homegreen Films.

2005. The wayward cloud. Taipei: Homegreen Films.

2006. I don't want to sleep alone. Paris: Centre National de la Cinématographie.

2007. It's a dream. Cannes: Cannes Film Festival.

2009. Visage. Paris: Musee du Louvre.

2010. Erotic space. Taipei: National Palace Museum. 
.2011. The theater in the boiler room. Taipei: Songshan Cultural and Creative Park. . 2012. Walker. Hong Kong: Hong Kong International Film Festival.

Uroskie, A. V. 2011. The philosophical toy as model: Duchamp, Breer, and the postwar emergence of cinema in the gallery space. Secuencias 32: 34-58.

Vagenas, M. G. 2013. Filmmaker Tsai Ming-liang says his work should be appreciated slowly. South China Morning Post (Hong Kong), 27 August.

聞天祥。《光影定格:蔡明亮的心靈場域》。臺北:恆星國際文化事業有限公司。2002。

江凌青。〈建築作為串連影像裝置與電影美學的關鍵：以蔡明亮的作品為例〉。《現代美 學學報》(23), 頁 51-79。2012. 